NEW LITERARIA-

An International Journal of Interdisciplinary Studies in Humanities

Volume 1, No. 2, November-December, 2020, PP 240-251

ISSN-2582-7375

DOI: https://dx.doi.org/10.48189/nl.2020.v01i2.027

www.newliteraria.com

\title{
Secular Dreams and Minority Question: Reading Disgraced with Talal
} Asad

\author{
Arju Khatun
}

\begin{abstract}
Edward Said in his Orientalism (1978) has developed the understandings of identity formation and otherisation based upon the distinction between ontology and epistemology, with an emphasis on humanitarian perspective. His book attempts to approach a heterogeneous and complex human reality in which the characters recognize and practice their individual agency. The minorities of a society have been pushed towards the fences under covert ideology of universalism and homogenization. The secular thinkers of the contemporary era have only underlined and applauded the assimilation project between diverse communities and few have addressed the terrorization and cancellation tolerated by the 'others or them'. After the incident of 9/11, the Muslim scapegoating has increased in bounds more than ever. This paper aims to discuss this pertinent issue with a 'contrapuntal reading' of the text Disgraced (2012) by Ayadh Akhtar in relation to Talal Asad's Secular Translations: Nation-State, Modern Self, and Calculative Reason (2018). Asad's argument that Islam in Europe has become "quasi-civilization identity" which threatens European civilization and their struggle to overcome the essentialism of the Muslims will help to understand Ayadh Akhtar's character Amir Kapoor's relation with the post 9/11 American state. This paper seeks to discuss the problems in a homogenous universal culture and tries to explicate how the due recognition of heterogeneous identity can address the subject of minority identity discourse in its complex entity.
\end{abstract}

Keywords: Religion, Secular, Minority, Modernity, Identity Politics.

\section{Introduction}

Ayadh Akhtar's Disgraced (2012) which won the 2013 Pulitzer Prize award for best drama, has much to contribute to the discourse and discussion of minority cultures and their reception in America, the celebrated dream place for the secular-modernists. Ayadh Akhtar, a Pakistan born American playwright with a keen fascination on religion and subtle politics that accompanies it has contextualized most of his works, for instance, The Invisible Hand (play) (2012), American Dervish (2012), the recent Homeland Elegies (2020) and Disgraced in the politico-religious conflicts in America and with America. Akhtar in his plays and novels has successfully portrayed the conundrum of religion, especially Islam, and the way it has been affecting the lives of its believers in a secular world. His productions particularly deal with the 9/11 America and its redefined relation with the Muslims. He talks about 
identity in America beyond the conundrum of American dream. To him, America has been transformed from the safe haven of the people to a flourishing economic market where those who can write the cheque can survive. Along with this he meticulously intertwines the identity question of the minorities. What is interesting about his works is that these do not vouch for any propaganda not are they promote any religious fundamentals. His stories and characters are layered within the intricacies of above conflicts without any direct answer. Very meticulously he draws on the characters and the various parts of their lives that have nothing to do with Islam but then everything to do with it. But he also brings out the lacuna or loopholes of the characters or the religions that cloud judgments of human beings. He does not try to give judgments to the characters for their weaknesses or incapability, which in a way can leave the readers confuse about his motifs. In a context like this emerge the characters of Disgraced, which portrays multicultural appearances of American society and also the hierarchical relation which binds them. The plot of Disgraced is based on the Muslim immigrants in America, and has a keen interest on Islamic doctrines and secular-liberal ideologies of developed America. To help understand these situations this paper draws on Talal Asad. With an interesting biographical past experiences of himself Asad has an oeuvre of anthropological works that circle around religions, secularism, liberalism, rituals in postcolonial world the readings of which are influenced by Foucault's method of genealogy of history. His works illustrate the emergence of the concept of religion with particular reference to Islam and Christianity and how it gives birth to the ideology of secularism in the wake of modernity or enlightenment. The books of Asad that this paper will be consulting have their context as the Muslim minority history in European states or more broadly in the First World countries that shout out for equality, liberty and fraternity across community. As a pioneer in the field of religious anthropology his literature helps understand the growing fear for Islam in the enlightened countries and the role of European modernity and secularliberals behind the uprising saying that 'all Muslims are terrorists'. Disgraced touches on the possibilities and failures of Muslim acculturate but never exactly try to pin point the reasons or the needs for that. Asad's take on the ideology of secularism and the European imperialism over other communities can help in contextualizing the need for the Muslims characters to assimilate and more often than not the failure to do so. The later part of this paper briefly discusses Asad's definitions of secular-liberal and how it is producing certain dominant narratives while blacking out other micro narratives. This mode of reading helps us grasp the conflicts in the play Disgraced, the questions and confusions that have been kept up in the air.

The first part of the paper deals with a brief but detailed analysis of the play and brings out the moments of crisis in the play. Later on it brings in Asad's readings to decipher the tensions in the text, specifically, the fallen fate of Amir Kapoor, the protagonist in post 9/11 America.

\section{Disgraced: A brief critical analysis of the text.}

Ayadh Akhtar is best known for his play Disgraced, although his most recent novel Homeland Elegies, a fiction cum memoir which deals with the contemporary politics and immigrant problems in America, is on the news. To go back to Disgraced, this play brought him success overnight and was a sold-out play in Broadway. The characters in the play come from different communities with their individual struggles and opinions. At the centre of them Akhtar creates Amir Kapoor, a second generation Muslim immigrant in America who describe himself as a sceptic, heavily consumed in the American lifestyle and married to a white woman artist who has been influenced by Islamic tradition and culture. Ayadh Akhtar presents Amir as an atheist or specifically a nonbeliever of Islam, but the subconscious of 


\section{Secular Dreams and Minority Question: Reading Disgraced with Talal Asad}

Amir is still struggling to maintain distance from the preaching of Islam. These gaps in his mind are poked by the circumstances and characters around him. The play unravels the need for Amir and other Muslim characters to change their identity in American soil. But even after all the imitation he fails to be a part of the American identity. The discussion below tries to manifest the catalysts in Amir's journey to show how the larger politics of the state affect an individual's life and the secular-liberal facade of progressive states which are supposed to take care of the individual.

The play begins with Emily, the white American (liberal) wife sketching the portrait of Amir, her husband, who once belonged to Pakistan, 'reproducing' Portrait of Juan de Pareja of Velázquez. It begins as:

Amir. I still think this is a little strange.

Emily. (sketching). Yeah ...

AMIR. That you want to paint me after seeing a painting of a slave.

EMILY. Juan de Pareja was Velázquez's assistance, honey. And a painter in his own right.

AMIR. And his slave.

EMILY. Until Velázquez freed him. (Beat.) (Italics. mine)

AMIR. No idea what that has to do with what happened last night.

EMILY. A man, a waiter, looking at you. (italics mine)

AMIR. Looking at us.

EMILY. (continuing) Not seeing you. Not seeing who you really are. Not until you started to deal with him. And the skill with which you did that.

AMIR. The guy's a racist. So what?

EMILY. It got me thinking about the Velázquez painting. And how people must have reacted when they first saw it. They think they're looking at a picture of a Moor. An assistant.

AMIR. A slave.

EMILY. Fine. A slave. . . . I don't know what you're so worried about. It's not like anybody's gonna see this. (Akhtar, 2012, p. 8)

Much significant information comes out of this short span of dialogues. Velázquez a seventeenth century court-painter to Philip IV of Spain brought Juan de Pareja from Alcazar, Rome where Pareja used to work. He brought Pareja as an enslaved artist who would assist him in his paintings. This particular painting which has been applauded by his contemporaries for speaking the 'truth' is a result of practicing which Velázquez has done before doing the portrait of Pope Innocent X. To improve his style Velazquez adopted impressionistic brush which gives the portrait certain 'vitality'. The portrait of Pareja was by no means a work of musing but a practicing on an enslaved moor.

Emily is intrigued by a scene in a restaurant where his brown husband experienced racism. She is captivated by the way Amir dealt with the waiter and made him see the 'gap' between what the waiter is assuming and what Amir really is. Emily is trying to romanticise the painting as something different from the slave-master relationship and as some artist and subject (or muse, as Emily tries to puts it). Amir and Pareja both are well established in their lives but their representation by their masters shadowed their own individual identity. The play begins with the same painting where Emily trying to represent Amir in an American society and ends in the hands of Amir looking at this painting trying to find himself. This painting of Amir brings Emily certain recognition in the artist's sphere. While Amir at the beginning is trying to reflect on the truth that Pareja was a slave or Moor for Velázquez, 
Emily insists on the concept of muse. This show the power dynamics between the two where she creates a discourse with her holds on knowledge and Amir successfully succumbs to that. Other than this particular power dynamics which have been continued throughout the play, this particular scene also shows the representation of oriental identities. Emily gives Amir a certain identity in "an Italian suit jacket, with a crisp, collared shirt . ..," (Akhtar, 2012, p. 8) an identity that Amir longs for in the American society to assimilate but at the same time it is not the identity of the "authentic" American, but a mimicry or the diluted form of the original one. Emily uses Amir as the object of inspiration, an object that can be exoticised like the painting and the story of slave-assistance Pareja. Amir is imprisoned by his portrayal although he does know that he is being used as a supplement for the slave-assistance. Part of Amir's identity wants to believe that he can be a part of the white culture, just as this painting portrays him even if it costs his individual identity.

Having set the stage in the above dynamics Akhtar goes on to develop the plot with the characters' past lineage and future consequences. We come to know that Amir Kapoor, who is originally from Pakistan, has changed his name from Amir Abdullah to Kapoor and presented himself as an Indian. He does not practice any religion because of some earlier experiences that he have had with his mother who said him to hate the Jews because Allah has said do. He criticizes Islam for its failure in separating mosque and state, he thinks of himself as an 'apostate'. Not only Amir but his nephew Hussein Malik too has changed his name into Abe Jenson. In the second scene, Abe Jenson comes to Amir to implore him to fight the case of Imam Farid who has been accused of fundraising for a mosque. Again in this scene Emily tries to convince Amir to take the case of Imam. When Amir asked Emily what she has seen in Islam that she is trying to defend the Imam, she refers to the pillars and arches of the mosques saying that "there is so much beauty and wisdom in the Islamic tradition, Amir" (Akhtar, 2012, p. 14). Again she is romanticizing the objects and inspirations. She successfully convinces Amir saying that the Imam needs one of his own men, in spite of Amir trying to object that he does not belong with the Imam.

In the following scene we are informed that Amir has attended the trial of Imam but the newspapers published him as a supporter of the Imam which has been worrying him. He knows that such kind of contacts would make him susceptible to the government and might affect his job. Although when Amir tries to talk to Emily she refuses to believe in his tensions.

Emily has a fascination for the Islamic art, she thinks of those as sacred which are not affected with the advent of secular. Isaac, a white-Jewish American man who later have an intimate relation with Emily, questions her devotion towards Islamic art as something orientalist. Emily believed that the Islam has never experienced renaissance like Christianity, it has not turned away from the bigger concept of God in search of modernity or secularism and that makes it special to her. While people like Emily or Isaac are dazzling over the arts of Islamic tradition, Amir is struggling to keep up his job which is now questioned because of his presence in Imam's hearing. Emily goes to extent to defend veil, not recognizing the politics behind that which might affect the reputation of his husband. She is the very epitome of white liberator who happens to respect all religions. Or, in other words she has the privilege to act as the liberal who endorses Islamic arts and goes to the mosque which her husband does not possess.

The third scene of the play brings out the catastrophic situation in Amir's life. Three months after the hearing, Emily brings guests in their house, Isaac and Jory, an AfricanAmerican woman who happens to be Amir's colleague. This culminating scene enkindles the 


\section{Secular Dreams and Minority Question: Reading Disgraced with Talal Asad}

tragic flaw in the character of Amir. Isaac and Emily starts their discussion on rich Islamic tradition and Emily's new found talent through the painting of Amir which she did at the very beginning of the play. To them, the young artists are trying to find the sacredness in art pieces which are embellished in the Islamic heritage. Amir in his usual self tries to criticise the Islamic tradition reminding that the Quran has no acceptance for paintings of creatures. Amir constantly speaks against Islam and blames it for its primitiveness. Contrary to him the other three are elaborating on the fact that we should differentiate between Islamo-fascism or the political use of Islam and the faith of the particular religion Islam. Amir here expresses that he felt a little proud in the 9/11 after bursting out on the conservativeness of the Islam:

AMIR: .. . And so, even if you're one of those lapsed Muslims sipping your after dinner scotch alongside your beautiful white American wife - and watching the news and seeing folks in Middle East dying for values you were taught were purer - and stricter - and truer . . . you can't help but feel just a little bit of pride.

ISAAC: Did you feel a pride on September $11^{\text {th }}$ ? (Beat)

AMIR: (With hesitation) If I'm honest ... yes. ...

AMIR: I was horrified by it, okay? Absolutely horrified.

JORY: Pride about what? About the towers coming down? About people getting killed?

AMIR: That we were finally winning.

JORY: we? (italics by Ayadh)

AMIR: Yeah ... I forgot ... which we I was. (italics by Akhtar)

JORY: You're an American. . .

AMIR. Its tribal, Jor. It is in the bones. You have no idea how I was brought up. You have to work real (italics by Akhtar) hard to root that shit out. (Akhtar, 2012, pp. 3839).

This heat up the conversation and suddenly Isaac now has a suspicious look on Amir as some 'closet jihadist' while Jory thinks that perhaps Amir is disturbed by the changes in his position at the office. At the farm where Amir used to work, they did an investigation after Amir's presence at the court hearing of Imam and now they think that Amir represented the Imam. Isaac thinks that Amir is taking a revenge on the white culture and having a white American wife is his way of showing that he has the master's wife. Amir and Jory come to know that Isaac and Emily are having an affair which angers them. In a heated face-off Amir spits on the face of Isaac when the latter was coming for Amir. Later when Isaac and Jory leave, Emily confesses on the affair to which Amir reacts as:

(All at once-Amir hits Emily in the face. A vicious blow. The first blow unleashes a torrent of rage, overtaking him. He hits her twice more. Maybe a third. In rapid succession. Uncontrolled violence as brutal as it needs to be in order to convey the discharge of a lifetime of discreetly building resentment. After the last blow, Amir suddenly comes to his sense, realizing what he's done.) (Italics by Akhtar) (Akhtar, 2012, p. 45)

In the last scene Emily comes with Abe who was stopped by FBI for terrorist remarks, to Amir so that he can help. We come to know that Amir and Emily no more live together. Amir is sorry for what he has done and Emily expresses that she too was responsible for what has been happened to Amir. She realises that her blindness towards arts and fascination for Islam make her unseen the damage that affect Amir who has been trying 
to change his social in America.

Interpreting Amir's spitting and hitting would be a difficult task. Ayadh Akhtar kept it open-ended for readers to interpret from their own position. Amir's reaction to Emily after hearing about the affair can never be justified on any ground, neither religion nor anger or frustration. But just before the hitting Akhtar's description of Amir's expressions needs to be analysed, "Uncontrolled violence as brutal as it needs to be in order to convey the discharge of a lifetime of discreetly building resentment" (Akhtar, 2012, p. 45). What 'resentment' he is referring to? Is this the resentment for Emily or Amir himself? Or it for the whole white liberal-secularist culture the Amir tried to fit in but failed? From the last scene of the play the readers are informed that Amir does not hate Emily for anything but he is certainly disappointed on himself who has neither recognition nor any respect for him. Abe, who is now wearing a skullcap, before leaving the stage at the very end expresses rather angrily to Amir,

For three hundred years they've been taking our land, drawing new borders, replacing our laws, making us want be like them. Look like them. Marry their women. They disgraced us. They disgraced us. And they pretend they don't understand the rage we've got? (Akhtar, 2012, p. 50)

If these lines of Abe are taken into consideration while interpreting Amir, is it possible then that the disrespect or disgraced for Muslims that Americans harbour led Amir to disgrace him? The person who has changed his original identity in this world has been accused of supporting terrorism. But before that, why Amir or Abe felt the need to change their name, religion and why is Amir trying so hard to assimilate to the host culture of secular America. Amir certainly felt difficulty in washing out the religious dogmas and orthodoxies that are attributed with Islam. But he has been trying to do that for a better future and to be an original part of American identity. Amir chooses to be Indian Muslims than a Pakistani because supposedly peoples of India are more liberal and secular than those of Pakistan. He knows that Islam has been accused of for being a stagnant religion that failed to incorporate modernity and renaissance within it. But artists like Emily are romanticising these same characteristics as something that inhabit the spiritual. But what complicates is that this one character of Islam brings in different result in the lives of Emily and Amir. Emily now has been celebrated as young oriental artist who researches on Islamic art tradition and gives them a certain representation just like she did for Amir. Amir knowing that he can't celebrate Islam is trying to create his identity through the pencils of Emily. Lives of people like Abe, Imam Farid or Amir are surrounded by surveillance. Imam Farid was trying to collect money for mosque just like any other religious institutions do for it. In the cafe where Abe with his friend Tariq got interrogated by the FBI, the situation was like this as Abe speaks,

ABE. We were at Starbucks. Just drinking coffee. Tariq starts talking to this barista who's one break. . . . she starts asking about our kufi hats and are we Muslims. And then she asks how we feel about Al-Qaeda. So Tariq tells her. Americans are the ones who created Al-Qaeda. (Akhtar, 2012, p. 47)

It's interesting how the pattern of question goes from 'are you Muslims?" to "do you believe in Al-Qaeda?" These sorts of misrepresentations and prejudices for the Muslims of the world forced Amir to censor himself. It must be noted that the girl in the cafe is first intrigued by the cap. The very appearance of individuals be it headscarves or caps arise questions on their human identity. It's the hegemonic knowledge that is used to create the power relations where the Muslim minorities are the victims who needed to be saved by the 


\section{Secular Dreams and Minority Question: Reading Disgraced with Talal Asad}

white secularists. This whole capital of modernity or secular-liberal attitudes, the lack of which make the Islam 'illiberal' and the believers of that religion terrorists. But why Amir has not been accepted by the host culture after projecting a life of admiration towards it? Even after being the secular-liberal, a good employee, a perfect English man in his appearance he has been outcast by the first secular-liberal culture of this world, which is supposed to be Euro-American culture.

\section{The spectra of Christianity and European secularism: A discussion on the concepts of 'religion' and 'secular' with reference to Disgraced.}

Amir's failure in being a part of the secular liberal society because of his religion prompts question on the discourses of 'religion' and 'secular'. Isn't secularism supposed to give equal right and dignity to every religion and individuals irrespective of their political obligations? Is not America the dream place for modernity, reason and liberal attitude that offers equal opportunity everyone? Then what goes different with Amir? Is there any lacuna in the disciplines of religion and secular then?

Talal Asad is an anthropologist who works on the genealogical studies of 'religion' and 'secular' with particular interest in Christianity and Islam, as his area of studies specifically in European countries. One of his first books Genealogies of Religion-Discipline and Response of Power in Christianity and Islam (1993) traces the history of religion, how it came to be formed as it is now. He starts with the claim that religion and power are not separate units in a society but it is the "oriental search for an essence of religion that invites us to separate it conceptually from the domain of power" (Asad, 1993, p. 29)i. He believes that what we today called "religion" is result of Christian attempts to combine rules and regulations, doctrine and practices, "even if that was a state never fully attained" (Asad, 1993, p. 29). Citing Clifford Geertz's definition of religion as symbolic representation, Asad goes on to dig the concept of symbol itself and come to the comment that representative of something (discourse/discipline) is authoritative and dependent on other production of discourses (p. 31). Then if religion is some kind of discourse produced by a particular society the opposite of that, the secular profane is also the making of that society and both are interlinked. He comments that it is Geertz's modern attitude that pushes him to separate the two discourses ${ }^{\text {ii }}$. Be it Christianity or Islam the practitioners of the rituals not always know about the theological disposition behind those. It is the authority behind that that creates what is to be called religion and what must be marginalized as secular. The authority fears of splitting the symbols of religion, the Truth. Asad recounts that the medieval church although always kept separate the sacred and profane but it did not try to establish "absolute uniformity of practice" and allowed exceptions but it endeavoured "subjection of all practice to a unified authority" (Asad, 1993, p. 38). It was late in the hands of Christian fathers that religion formed on "authorized practice and authorized doctrine" because of the fear of alternative truth and knowledge. Until this time the idea of secular has been interrupting many a times but the Church authority always preferred the Church and Christian doctrines that prevailed according to the institutions of power. Asad writes, "in later centuries, with the triumphant rise of modern science, modern production, and the modern state, the churches would also be clear about the need to distinguish the religious from the secular, shifting, as they did so, the weight of religion more and more onto the moods and motivations of the individual believer" (Asad 1993, p. 38). But what were the causes that result this foundational change and more importantly, was the motive behind this change truly liberal or power play of the emerging new institutions!

His Formations of the Secular: Christianity, Islam, Modernity (2003) is a work of 
anthropology which is scattered through different time and space, covers various disciplines while tracing the journey of religion along with secularism. Asad reads religion and secularism as products of politics which had been created for the development of nation-state and modernity. Religion and secularism, the binary that is created by modern thoughts as Asad says, become the locus of power. He begins with a background study on secularism and traces the genealogy of the secular doctrine in Western Europe's modernity project. Asad brings out the point of liberal democracy of modern nation-state and need for secularization. His method of understanding history has an undertone of Foucauldian method and deconstruction where he tries to break the binary of religion and secularism as modern necessity and also to challenge the belief that secularism as a discipline is solely found in Europe first and with the expansion of colonies it had spread to the outer world. Citing Geertz, the eminent anthropologist, he refers to the need to imagine a homogeneous time as something prerequisite to think of "individual lives that comprises a (national) community in which there are no privileged persons or events, and therefore no mediations" (Asad, 2003, p. 3). Secularism does not need the mediation of any authority but it would be providing "direct-access" to the individual subjects irrespective of religion, gender, law, class or race. What Asad argues that the liberal government has used secularism as a statecraft or political strategy that would not use force or consent but can do the same in the name of participation, self-discipline and ruling citizens. He writes, "Secularism is not simply an intellectual answer to a question about enduring social peace and toleration. It is an enactment by which a political medium (representation of citizenship) redefines and transcends particular and differentiating practices of the self that are articulated through class, gender and religion" (Asad, 2003, p. 5). He points out to the fact that the religious anthropologists hitherto in order to define religion and secularism have focused on the homogenous time without considering the societies and states that include heterogeneous lives and the approach on and of minorities towards secularism. Asad comments that while secularism is not European it has grown closely with the rise of capitalist nation-state. Thus he adds the element of economy with the birth of secularization. The project of modernity has been a 'hegemonic political goal' that a fledged nation-state has to achieve to show its power to others. Secularism and disenchantment of world are criterions of this process of modernization that have been followed sooner or later. While Asad is reading the genealogies of religion and its side-effects, his method also has some elements of countering the western hegemony based on secular world arguing that religion and secularism are not poles apart but something interconnected. He is showing how the enlightened knowledge of the Europeans had brought the religion from the ontological domain to the cognitive function where it is functioning merely as religious symbolism. Modernity as a political-economic project "constructs categories of the secular and the religious in terms of which modern living is required to take place ... for representations of 'the secular' and 'the religious' in modern and modernizing states mediate people's identities, help shape their sensibilities and guarantee their experiences" (Asad, 2003, p. 14). Secularism, which comes with the belief that it would bring individuality of the subjects and would free them from the fear of unseen and supernatural Gods, it seems, works on political structures that still maintains inequality in the name of egalitarian society.

With these references above Asad opines that both religion and seculariii are the need of time. These concepts have been produced to suit the political and economic purposes of the particular time and space. Europe needed a denominator of every religion during their colonial expansion to soothe the process of empire building and for that the ideology of secularism fitted the purpose. Along with that the liberal concepts of individual rights helped Europe spread the spectra of enlightenment. It must be noted that classical liberalism was primarily for the rights of private property. Somehow this whole redemption or the rebirth of 


\section{Secular Dreams and Minority Question: Reading Disgraced with Talal Asad}

individuals through reason, liberal-secular beliefs are turned out from the base of economy. With all these backgrounds Asad believes that modernity has not ended the dogmas of religion but it has only reformulated pushing in it the private sphere of individuals. Like the church now the state has adopted the role of surveillance. Secularization is one window of the panoptican. If one does not fit into the role prescribed by the state, the individual would be labelled as minority then gradually would be removed from the citizenship rights. The goal of becoming 'abstract and universalised' through the ideology of secularism has been grounded on the concept of 'homogeneity' ${ }^{\text {iv }}$. This homogeneity is specifically a product of European enlightenment that planned the project of modernity with their own history and forced the others to obey those to become a part of the modern state. It fails to incorporate the other religions and their particular history making their own the hegemonic and ideal culture. Liberating individuals from any kind of authority and more importantly from the hegemony of religion is something peculiar to Christian beliefs situated in the context of "enlightened-modern-coloniser" states. Understanding of religion and its practices, till the present time, varies drastically in other countries. This created a hierarchy among the religions where now the secular state wants the individuals to practice particular life and culture that is best suited for the state. Asad further adds in his book Formations of the Secular, "the interesting view about this view is that although religion is regarded as alien to the secular, the latter has also seen to have generated religion . . . in the modern present secularism has produced enlightened and tolerant religion" (Asad, 2003, p. 193). The irony keeps floating here: it is not that religion has vanished but the historical time and space that tried to free itself from religion was different from now and the particular moment of disruption in the church and state of Europe was different from other parts of the world which might not have shared the same thoughts. Even today practicing religiosity and the secular belief are different and singular in their own context.

With these fluid ideas of religion and secular Asad discusses Muslim minority in Europe and America in his book Formations of the Secular and also Secular Translations: Nation-State, Modern Self, And Calculative Reason (2018). In a liberal democratic society where state has the absolute power of equality and dignity are assumed as the identity of citizen. But those who are not legal citizens of the territory, the state have for them strategies of managing them outside the civil society. The Muslim minority in West has economic relation with the state but they can't have a relation of equity and dignity like the authentic Europeans or Americans. Treating someone equal presupposes recognition ${ }^{v}$ of that individual as she is, to accept her with her own identity. Interestingly, the west does not want to accept the Muslims as they are, even after being the supposed owner of secular doctrines. But why is that so?

Asad in chapter 'Secular Equality and Religious language' (2018) begins with the fact that the secularists believe that Christianity gifted secular liberal democratic concepts to the world. This particular belief and self-acclamation of the seculars as successors of Christianity excludes all those who cannot claim the Christian culture. This major characteristic has become the link of relation with the non-westerns. Asad points out that the language and practice of Christianity has been inherited by the secular state making it's the norm and put the other practices in trial. Liberals in this state does not question the economic or political inequality of others and its commitment for national security to identify enemies are making it an authoritarian state. To regulate the Muslim minorities in this situation would be necessary and rather an easy task.

Asad points out that the Muslims in West cannot claim inheritance to the western civilization as a Christian can do. The secular-liberal beliefs thus helped them tolerate the 
Muslims. The European civilization has a historical narrative which comprises a particular essence that is foreign to the Muslims. To them, modernity, enlightenment, Christianity industrialization all these have not been experienced by the Muslims. The Muslim community is the primitive tribal culture that Amir Kapoor is referring to. Islam has denied any connection with civilization on two grounds, as Asad writes,

“by denying that it has an essence of its own, 'Islam' can be represented as a carrier Civilization that helped to bring important elements into Europe from outside, material and intellectual elements that were only contingently connected to Islam. Then to this carrier civilization is attributed an essence: an ingrained hostility to all non-Muslims. (Asad, 2003, p. 169)

This particular essence of Islam, 'hostility to non-Muslims' becomes the defining character for them and of the European identity too. Islam has been attributed as a 'quasi-civilization identity' one consequence of the "corrupting moral environment" (p. 169) that Europe cannot include in their modern identity. The Muslims can only incorporate in West when they let go of their Islamic essence. Europe practices its hegemonic power to regulate and labels the others' identity. It has never opened or changed its own inherited Christian essence to make space for the Muslims or other minorities. It is the minorities whom always have to update with the changing norms but never the other way round.

Amir Kapoor has been trying to de-essentialize the Islamic components from him to be part of the European civilization. But this has not been enough for the host cultures. It's the facade of the liberal democratic state that failed to assimilate the minorities because of its glorious past inheritances. Their concept of homogenous time and linear space is particularly formulated on single 'civilised' culture as the marker. The other different cultures have to let go of its essences and imitate the touchstone to be civilized. If there has not been so much insistence on homogenous and universal culture, things would have been different for Amir and other minorities. Amir's presence in the trial ruined his career, the consequence of which cost his marriage life. Emily is not suspicious for talking about Islam or defending the veil but it is Amir who is put under surveillance. His inability to differentiate his religious root and the political relations make him vulnerable before the state. Being Muslim minority in West is not only to belong to certain faith but it puts him in a vulnerable condition always at the verge of breaking. Being a secular in an enlightened world means that people are "being able to live as autonomous individuals in a collective life that extends beyond national borders" (Asad, 2003, p. 180). Is American secularism able to practice this with its constant angst for the Muslims in their territory and outside the territory whom they feel the need to give lessons on democracy?

Asad offers 'complex space and heterogeneous time' against the secular space and linear time of liberal democratic state. To him 'complex space' could "intersect boundaries and heterogeneous activities of individuals as well as groups related to traditions" (Asad, 2003, p. 179). He defines 'heterogeneous times' as

"of embodied practice rooted in multiple traditions, of the differences between horizons of expectation and spaces of experience - differences that continually dislocate the present from the past, the world experienced from the world anticipated, and call for their revision and reconnection. These simultaneous temporalities embrace both individuals and groups in complexities that imply more than a simple process of secular time." (Asad, 2003, p. 179). 


\section{Secular Dreams and Minority Question: Reading Disgraced with Talal Asad}

Modernity has helped rational thinking to emerge but what is rational and what is irrational have been defined by one hegemonic culture. It excluded all other in-between characters. We no more can define ourselves in binary of 'us' and 'them'. There has to come a time when the complex essences of individuals and groups are recognized. Without recognizing the priorities of them, liberals or seculars cannot decide what is equal or what supposes their right or dignity. But in our contemporary time the binary of 'us' and 'them' have become far-reaching. Amir Kapoor who represents 'them' or the minority, his secular beliefs or liberal attitude has been questioned by the state simply because he belongs to Muslim minority group in America. But Emily's devotion for Islamic tradition or support for veil has passed unnoticed because of her Christian privileges. In other way it shows that the Muslims cannot be secular ${ }^{\mathrm{vi}}$. The more powerful secular Christian dogma has failed to dissect the infected parts from Islam and rather surprisingly is holding onto those. The characters' changes of name, identity, apparel are all examples of that. Amir is certainly aware of the primitiveness of Islam like any other aged religion. But the invisible force to practice European secularism creates confusion within him. The state's witch-hunting for Muslims brings out the vulnerable sides of the latter. If the state had recognised and allowed the minorities to live without holding them for constant surveillance, things would have been different. The primary rule of secularism that the state and church would be separated has been reformed in a way that other religious institutions have become victims in the hands of state. The state does not show respect for the Imam or Amir simply because their allegiance (however questionable that is) is to Islam. It is the failure of modern secular beliefs that fails to secure the basic interest of the minorities. Asad has rightly pointed out that secularism is becoming another religion in the hands of state that are proud of its economic development and glorious past.

\section{References}

Akhtar, Akhtar. (2012). Disgraced. Dramatists Play Service. inc.

Asad, Talal. (1993). Genealogies of Religion-Discipline and Response of Power in Christianity and Isla. The John Hopkins University Press.

Asad, Talal. (2003). Formations of the Secular: Christianity, Islam and Modernity. Stanford University Press.

Asad, Talal. (2018). Secular Translations: Nation-State, Modern Self and Calculative Reason. A Colombia University Press E-book.

\footnotetext{
${ }^{\mathrm{i}}$ Three major works of Talal Asad has been mentioned to address the different issues in the text Disgraced. These books discuss particular topics and history of different time and space which is necessary to know to understand the larger problem. All the books together hold understanding of certain topics e.g. religion and secular developed through ages.

ii Asad believes that it is the modern binary system that separated religion from secularism to fulfill the thirst of purification.

iiiTo Asad, the ideology of secularism has received more importance than the concept or the form of secular. Secularism has been used as a medium of mediation for the modern nation-state to influence the people accordingly and has created power hierarchy within the religions. While the larger and the basic of all secular concepts has been cornered.

${ }^{\text {iv }}$ This recurrence of 'homogeneity' has its reference in Benedict Anderson's concept of 'homogenous, empty time' produced by modern technology which helps arouse a sense of nationalism within the subjects. Anderson developed this idea from Walter Benjamin's “age of mechanical reproduction”. (Anderson,1983, p. 37)
} 
'This term 'recognition' has important connotation in the sphere of social science. It has been believed (mostly) by the Marxist feminists that to secure the process of 'redistribution' (another specific term related with economic equality) it is important to recognize the people as they are. This discourse has been emerged during the identity movement of late twentieth century to address the oppression and inequalities of various section of people not only with respect to sex but caste, religion, space, color, differently able, minorities, refugees and age. Works of Nancy Fraser and Iris Marion Young can be useful in this area of study. (See Fraser, Nancy. "Social Justice in the Age of Identity Politics: Redistribution, Recognition, and Participation". Redistribution or Recognition? A Political-Philosophical Exchange, edited by Nancy Fraser and Alex Honneth, Verso, 2003, pp. 7-109. And Young, Iris Marion. Justice and the Politics of Difference. with a new foreword by Danielle Allen, Princeton UP, 2011, pp. 3-65).

viThe argument that Muslims are not capable of secularism is expressed and believed by many prominent political thinkers, e.g. Derrida and Habermas. They believe that Islam comprises singular authority incapable of translation which makes it stagnant. (Quoted in Asad 60, 2018 and in Asad 47-57, 2018 respectively) (Derrida, Jacques. "Above all No journalists." Religion and Media, edited by Hant de Vries and Samuel Weber, Stanford U P, 1998, pp 56-93) (for further reading in Habaermas see Habermas, Jurgen. "Notes on Post-Secular Society". Blätter für deutsche und internationale Politik, translated by Tony Blair, April, 2008, pp. 1-14.)

\section{$\underline{\text { Bio-note }}$}

Arju Khatun is an M.Phil Scholar in Centre for Studies in Social Sciences, Calcutta. She had her MA from Aliah University in English Literature. Her research interest includes identity politics, cultural studies, postcolonial, literature and politics of religion. Currently she is working on Bengali Muslims as her M.Phil research thesis.

Email Id: arjukhatun6@gmail.com 